\title{
The genus Cyamiocardium Soot-Ryen, 1951 (Bivalvia: Cyamiidae) in sub- Antarctic and Antarctic waters
}

Matías R. Urcola, $1 \square$

Email matiasurcola@yahoo.com.ar

Diego G. Zelaya, 1,2

${ }^{1}$ Laboratorio de Malacología, Departamento Biodiversidad y Biología Experimental, Facultad de Ciencias Exactas y Naturales, Universidad de Buenos Aires, Intendente Güiraldes 2160, Ciudad Universitaria, C1428EGA Buenos Aires, Argentina

2 CONICET, Buenos Aires, Argentina

Received: 9 July 2017 / Accepted: 1 February 2018

\section{Abstract}

For more than 50 years the genus Cyamiocardium was regarded as represented by three species: Cyamiocardium denticulatum (with Cyamiocardium rotundatum as a synonym), Cyamiocardium dahli, and Cyamiocardium crassilabrum. However, in the last years, the latter was removed from Cyamiocardium, alternatively being placed into Perrierina. All these species were mainly based on the general shell morphology of a reduced number of specimens, with scarce (or no) information on their anatomy and reproductive traits. The present study provides the first systematic revision of the species of Cyamiocardium occurring in sub-Antarctic and Antarctic waters. For that, an extant source of material was available; and several characters not studied (in detail) before, such as prodissoconch morphology and microsculpture, gross anatomy, and reproductive characteristics, were investigated. As part of this study, the identity of $C$. denticulatum (the type species of the genus) and that of $C$. dahli are clarified. In addition, $C$. rotundatum is revalidated as a full species, and $C$. crassilabrum is transferred again to Cyamiocardium. Furthermore, three new species were detected and are described herein: Cyamiocardium chuanisinense new species, Cyamiocardium 
namuncurense new species, and Cyamiocardium yeskumaala new species. The new information arising from this study is used to redefine the genus Cyamiocardium, and to re-analyze the similarities/differences of this genus with other cyamiids.

\section{Keywords}
Mollusca
Cyamioidea
Biodiversity
Southern Ocean
Pampa Azul

\section{Electronic supplementary material}

The online version of this article (https://doi.org/10.1007/s00300-018-2275-8) contains supplementary material, which is available to authorized users.

\section{Introduction}

The genus Cyamiocardium was proposed by Soot-Ryen (1951) to relocate Cyamium denticulatum Smith 1907, a species described from the Ross Sea, Antarctica. Subsequently, four other species were included under this genus: Cyamium rotundatum Thiele 1912, from Gauss station, Antarctica; Cyamiocardium dahli Soot-Ryen 1957, from southern Chile; Cyamiocardium crassilabrum Dell 1964, from Malvinas/Falkland Islands; and Cyamiocardium domaneschii Passos and Machado 2014, from southern Brazil. The former was subsequently regarded by Soot-Ryen (1951) as a possible synonym of $C$. denticulatum, a synonymy ratified by Engl (2012). On the other hand, C. crassilabrum was transferred to the genus Perrierina Bernard, 1897 by Zelaya (2008). Cyamiocardium denticulatum was mentioned for numerous localities in Antarctic and sub-Antarctic waters (Lamy 1911; Melvill and Standen 1912; Powell 1958; Dell 1964, 1990; Linse 2002). The wide range of geographic and bathymetric distribution mentioned for this species opposes to that found in the other species of this genus, which are only known from their type localities or its adjacencies.

Currently, Cyamiocardium species appear mainly defined based on shell morphology alone. Even when Soot-Ryen $(1951,1959)$ commented on the great intraspecific variability of this character in C. denticulatum and C. dahli, the 
intraspecific degree of variation was never determined for Cyamiocardium species. Anatomical data on the species are also scarce. Soot-Ryen (1951) provided by first information on the gross anatomy of the genus, based on a specimen of

"Cyamiocardium denticulatum" (but see in the systematic section on the identity of this material). More recently, Passos and Machado (2014) provided further information on the genus, based on scanning electron microscopy and histological sections of $C$. domaneschii. When comparing the anatomical descriptions of $C$. denticulatum and $C$. domaneschii two main differences make evident: (1) the number of fusions along the mantle edge and, consequently, the number of mantle openings: a single one in $C$. denticulatum $v$ s. three in $C$. domaneschii; and (2) the morphology of the foot, which was described as digitiform, without a groove in the base, in the case of $C$. denticulatum, but with a sole and a groove in the base, in the case of C. domaneschii.

Osorio (1974) was the first author in describing the existence of brooding phenomena in "Cyamiocardium denticulatum." Passos and Machado (2014) also found this mode of reproduction in C. domaneschii.

The present contribution aims to perform a systematic revision of the species of Cyamiocardium inhabiting the sub-Antarctic and Antarctic waters, based on the study of morphological and anatomical characters. In addition, some aspects of the reproductive biology of this genus are also revised.

\section{Materials and methods}

This study is mainly based on specimens collected during several trips and expeditions to Tierra del Fuego, Isla de los Estados, Burdwood Bank, South Georgia, and South Orkney, aboard the A.R.A. Alférez Sobral, R.V. Polarstern, coastguard GC-189 Prefecto García, and A.R.A. Puerto Deseado (Fig. 1). All this material was collected using a trawl of $2 \mathrm{~mm}$ mesh-size net, and separated from the sediment under stereoscopic microscope. Additional specimens from the Beagle Channel, South Georgia, and Bellingshausen Sea (Antarctica), were made available by other researchers. The number of live collected specimens (spec) and valves (v) at each sampling locality is indicated in Online Resource 1. Such material was deposited in the collections of the Museo Argentino de Ciencias Naturales "Bernardino Rivadavia," Buenos Aires (MACN) and Museo de La Plata (MLP). Furthermore, the collections of the Museum für Naturkunde, Berlin (ZMB), National Museum of Scotland, Edinburgh (NMSZ), United States National Museum, Smithsonian Institution, Washington (USNM) and Los Angeles County Museum of Natural History (LACM), were searched for complementary 
information. For comparative purposes the type materials of all nominal species attributed to Cyamiocardium, were studied. This includes the types housed at the ZMB, Natural History Museum United Kingdom (NHMUK) and Swedish Museum of Natural History, Stockholm (SMNH). When the lots only had as reference the name of the site of collection, this site was personally georeferenced; in this case latitude and longitude are indicated with "[]." Shell morphology is described and illustrated using scanning electron microscope (SEM) photography. Additional figures of the species are provided in Online Resource 2. Shell measurements were obtained using an ocular micrometer, mounted on a stereoscopic microscope. The following measurements were considered: shell length $(L)$, maximum anteroposterior distance; shell height $(H)$, maximum dorsoventral distance, perpendicular to length; shell width $(W)$, maximum distance across valves. Morphometric ratio $W / H$ was calculated; the mean and standard deviation values and the number of specimens measured $(n)$ are given. Hinge teeth nomenclature is indicated in Fig. 2f.

\section{Fig. 1}

Study area showing the provenance of the material examined. a entire studied area, $\mathbf{b}$ enlarged detail of the squared area in a. Cyamiocardium denticulatum: filled triangle; C. rotundatum: triangle; $C$. dahli: square; $C$. crassilabrum: lozenge; $C$. chuanisinense new species: type locality: W with lower case ("w" instead of "W") hite square containing black, other localities: filled square; $C$. namuncurense new species: type locality: fisheye, other localities: circle; C. yeskumaala new species: type locality: W with lower case ("w") hite diamond containing black, other localities: filled circle 



\section{Fig. 2}

Cyamiocardium denticulatum (a-f) and C. rotundatum (g-l). a paralectotype (NHMUK 1905.9.25.26), b-f specimens from King George Island, South Shetland, $50 \mathrm{~m}$ (ZMB-Moll 114.653), g holotype (ZMB-Moll 63116), h specimen from Bellingshausen Sea, 94 m (MACN-In 41444), i-l specimens from South Orkney, 402 m (MACN-In 41443), a, b outer views right valve, $\mathbf{c}, \mathbf{i}$ inner view left valve, $\mathbf{d}, \mathbf{j}$ inner view right valve, $\mathbf{e}, \mathbf{k}$ detail of the prodissoconch sculpture, $\mathbf{f}, \mathbf{I}$ hinge plates (left valve upper, right valve lower), $\mathbf{g}, \mathbf{h}$ outer views left valve. Scale bars $\mathbf{a}-\mathbf{d}, \mathbf{g}-\mathbf{j}$ : $1 \mathrm{~mm}$; e: $20 \mu \mathrm{m}$; f, l: $500 \mu \mathrm{m}$; j:k: $5 \mu \mathrm{m}$. $a c$ anterior cardinal, $m c$ median cardinal, $p c$ posterior cardinal, lig ligament, $p l$ posterior lateral

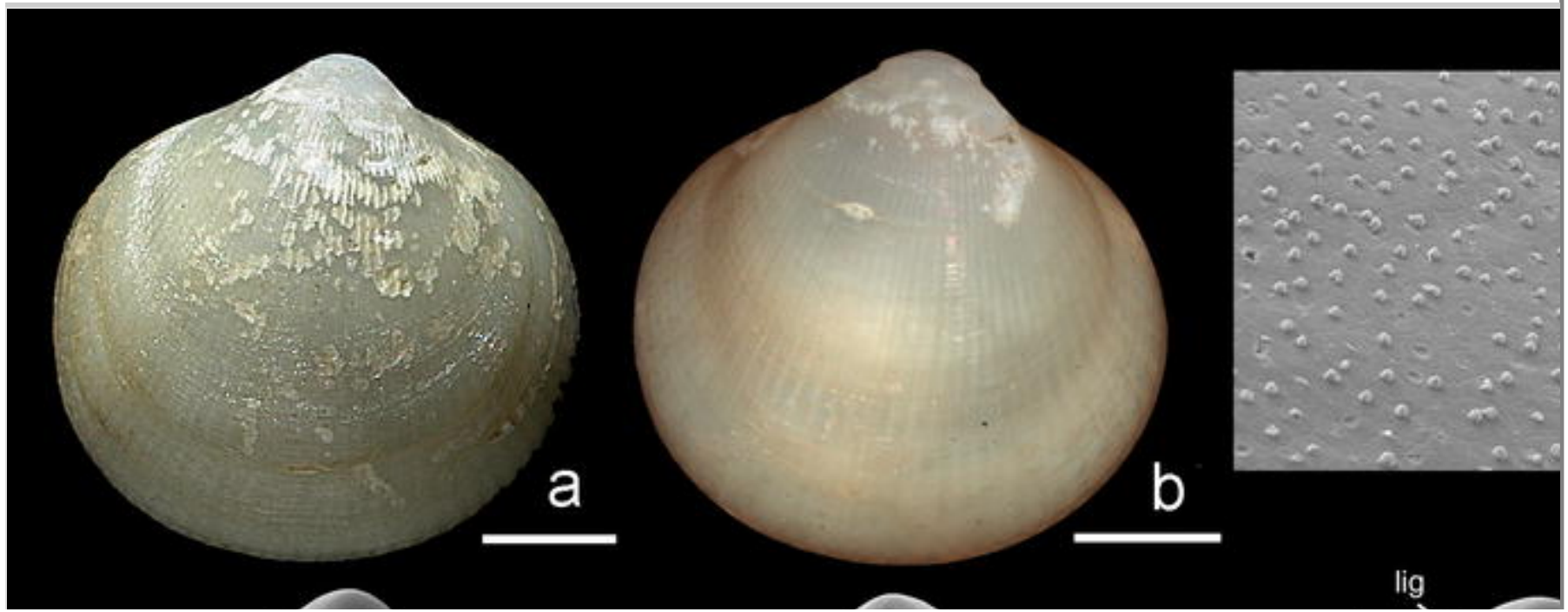



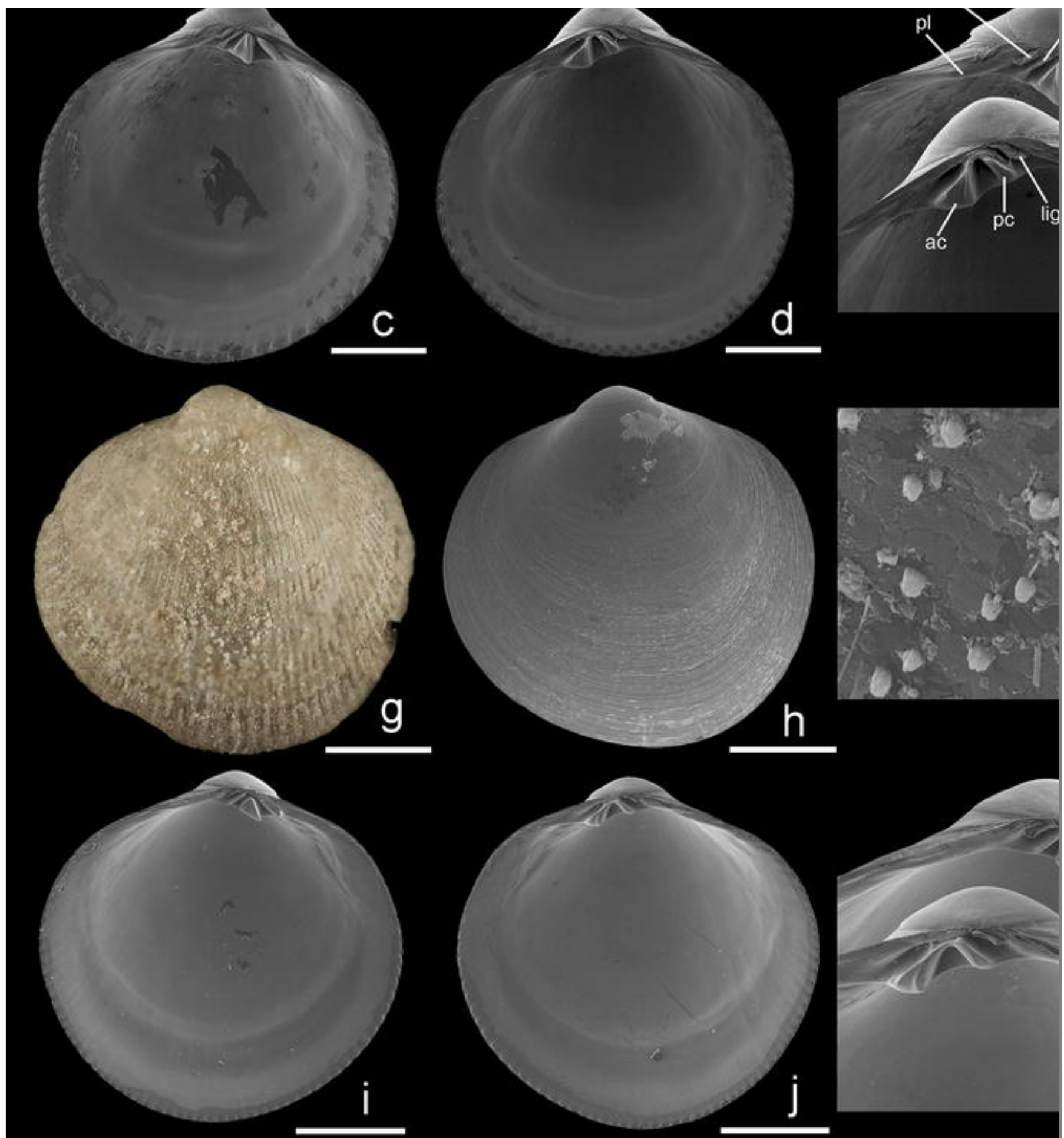

Information on the gross anatomy comes from the study of at least five specimens per species, dissected under stereoscopic microscope; illustrations are provided in Online Resource 2, Fig. 7. Additionally, four specimens of $C$. denticulatum and $C$. dahli, and two specimens of $C$. chuanisinense new species and $C$. namuncurense new species were histologically studied. For that, specimens were decalcified by rinsing in Bouin solution for $24 \mathrm{~h}$, dehydrated and embedded in Paraplast ${ }^{\circledR}$ before sectioning. Serial sections ( $4.5 \mu \mathrm{m}$ thick) were stained with hematoxylin/eosin. 


\section{Systematics}

Genus: Cyamiocardium Soot-Ryen, 1951

Type species: Cyamium denticulatum Smith, 1907

\section{Redescription of Cyamiocardium}

Shell small among bivalves, equivalve, sculptured with radial ribs that produce crenulations in the inner margin of shell, and thin to thick commarginal lines. Umbones subcentrally located, anteriorly projected. Prodissoconch large, clearly differentiated from dissoconch, smooth in appearance, but usually with distinctive microscopic ornamentation when viewed at higher magnification. Periostracum thick, forming notorious commarginal folds. Hinge plate forming a continuous shelf, extending both anterior and posteriorly to the umbones, wider anteriorly. Right valve with two well-developed, straight, joined at the base and divergent (anterior and posterior) cardinal teeth; and a well-differentiated posterior lateral tooth which, together with the dorsal margin, forms a depression where fit the posterior lateral tooth of the opposite valve. Left valve with three cardinal teeth: an anterior, elongated, and solid cardinal tooth; a strong and triangular median cardinal tooth; a laminar posterior cardinal tooth; and a posterior lateral tooth. Left and right valves sometimes with additional tubercles anterior and posterior to umbones, resembling a taxodont hinge. Ligament internal, located in a narrow and elongated resilifer, behind the posterior cardinal tooth; an external, thin (periostracal) ligament, also present. Pallial line entire. Mantle with a large pedal opening and one or two posterior siphonal openings. Two rows of tentacles run along the posterior fused area, where sometimes additional tentacles are also present, particularly surrounding the inhalant aperture. Anteriormost part of pedal aperture with some smaller tentacles. Anterior adductor muscle elongated; posterior adductor muscle ovate, smaller than the anterior one. Foot with well-differentiated heel, narrow sole, byssal groove, and a large glandular complex ("byssal gland"), which produces a single, thin byssal filament. Ctenidia formed by two demibranchs at each side; each demibranch comprising both ascending and descending lamellae. Right and left inner demibranchs posteriorly fused between them and to the mantle margin. Animals dioecious. Embryos brooded, attached to the inner demibranch. A continuous layer of follicular cells surrounds the oocytes and embryos, during all the development. 
(Figures 1a,2a-f, 5a-c and 6a; Online Resource 2: Figs. 1, 7 a, h)

Cyamium denticulatum Smith 1907: 3, pl. 2, Figs. 16-16b.

Cyamiocardium denticulatum: Nicol 1966: 57-59, 94, pl. 7, Figs. 2, 3, and 6;

Mühlenhardt-Siegel (1989): 165, pl. 3, Fig. 32 and pl. 7, Fig. 32; Dell (1964): 203, 204 [in part]; Dell (1990): 50, Figs. 80-83 [in part]; Narchi et al. (2002): 666, Figs. 31-33; Engl (2012): 55, pl. 9, Fig. 6a, c [in part].

Cyamiocardium crassilabrum: Absher \& Feijó 1998: 442, Fig. 4P [non Dell 1964].

NOT Cyamiocardium denticulatum: Melvill \& Standen 1912: 363 [is $C$. namuncurense]; Soot-Ryen 1951: 25-27, Figs. 7, 8 [is C. rotundatum]; Dell 1964: 203, 204 [is C. dahli, C. chuanisinense and C. yeskumaala; in part]; Osorio 1974: 7-10, Fig. 1a-c [is C. rotundatum]; Dell 1990: 50, Figs. 80-83 [is C. dahli, C. chuanisinense and C. yeskumaala; in part]; Absher \& Feijó 1998: 442, Fig. 40 [is C. rotundatum]; Linse 2002: 59 [is C. yeskumaala]; Aldea \& Troncoso 2010: 202, 203, Fig. 239a, b [is C. rotundatum]; Engl 2012: 55, pl. 9, Fig. 6a, c [is $C$. rotundatum; in part].

NOT Cyamiocardium cf. denticulatum: Hain 1990: 95, 96, pl. 14, Fig. 6a, b [is $C$. rotundatum].

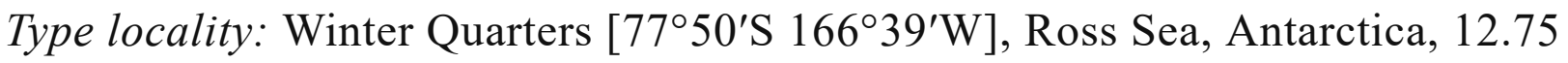
fathoms.

Material examined: Lectotype (NHMUK 1905.9.25.25), a paralectotype (NHMUK 1905.9.25.26) and 20 additional lots (see Online Resource 1).

Distribution: South Georgia, South Shetland, Antarctica (Fig. 1a). Living specimens: 5-507 m depth.

Description (Fig. 2a-f, Online Resource 2: Fig. 1): Shell large for the genus (maximum $L=5.3 \mathrm{~mm})$, inflated $(W / H=0.72 \pm 0.04 ; n=18)$, solid. Shell outline ovate to subquadrate. Anterodorsal and posterodorsal margins sloping straight, at similar angles; the posterior slightly longer than the anterior one; both forming a weak angulation at its junction with posterior and anterior margins. Ventral margin uniformly curved, continuous with anterior and posterior margins. Posterior end as high as anterior end. Umbones prominent, high and wide, well outstanding from dorsal margin. Prodissoconch of about $660 \mu \mathrm{m}$ L, subcircular; microsculpture 
consisting of minute, irregularly distributed, widely separated granules. Dissoconch whitish, dull; sculptured with 42-44 low and wide radial ribs and thick commarginal lines. Periostracum yellow ocher, sometimes with one or two darker commarginal color bands. Escutcheon narrow, elongated, sunken. Inner surface of shell whitish, dull; margins strongly crenulated. Hinge plate solid, slightly sinuated below umbo in the right valve. Right valve: anterior cardinal markedly widened towards the distal part; posterior cardinal uniform in diameter, almost a half the size of anterior cardinal; posterior lateral tooth elongated, narrow, moderately solid. Left valve: median cardinal with short base and anterior side slightly longer than the posterior one, having a deep sulcus that extends from the base to the cusp, giving the appearance of a bifid tooth; posterior cardinal short and straight, directed towards the posteroventral margin, extending all along the height of the hinge plate; anterior cardinal delicate, somewhat longer than posterior cardinal, anteroventrally directed; posterior lateral tooth moderately solid, well outstanding from dorsal margin. Internal ligament extending for one half of the height of the hinge plate. External ligament posterior to umbones and between prodissoconchs.

Anatomy (Fig. 5a-c; Online Resource 2: Fig. 7a, h): Mantle margin largely free for about four fifths of its total length, posteriorly fused forming a single permanent siphonal opening. Fusion involves the inner mantle fold and, at the posteriormost part, just below the posterior adductor muscle, also to the middle mantle fold. Along the fused area and in the posterior part of the inhalant-pedal opening, 24-30 pairs of tentacles, present. Ctenidia with axis almost vertical. Inner demibranch triangular, longer than high; with about 50, anteroventrally directed filaments in larger specimens; outer demibranch one-third the size of inner demibranch, with up to 40 filaments. Ascending lamellae of inner demibranch approximately one half the height of descending lamellae; descending lamellae of outer demibranch approximately one half the height of ascending lamellae.

Remarks: The name "Cyamiocardium denticulatum" appears usually used in the literature to refer to material that does not correspond actually to this species. This is the case of the material reported by Melvill and Standen (1912) from the Malvinas/Falkland Islands, Dell $(1964,1990)$ from the Strait of Magellan, Tierra del Fuego, Cape Horn and Isla de los Estados, and Linse (2002) from the Drake Passage and Cape Horn; as well as the material figured by Soot-Ryen (Soot-Ryen 1951; Figs. 7, 8), Hain (1990; Fig. 6a, b), Osorio (1974; Fig. 1a-c) and Aldea and Troncoso (2010; Fig. 239). The identity of all these materials is discussed bellow. 
(Figures 1a, 2g-1; Online Resource 2: Figs. 2, 7b)

Cyamium rotundatum Thiele 1912: 231, pl. 18, Fig. 20.

Cyamiocardium rotundatum: Egorova 1982: 72, 133, Figs. 328, 329.

Cyamiocardium denticulatum: Soot-Ryen 1951: 25-27, Figs. 7, 8 [non Smith, 1907]; Osorio 1974: 7-10 , Fig. 1a-c [non Smith, 1907]; Absher \& Feijó 1998: 442, Fig. 4O [non Smith, 1907]; Aldea \& Troncoso 2010: 202-203, Fig. 239 [non Smith, 1907]; Engl 2012: 55, pl. 9, Fig. 6b [non Smith, 1907; in part].

Cyamiocardium cf. denticulatum: Hain 1990: 185-186, pl. 14, Fig. 6a, b [non Smith, 1907].

Type locality: Gauss Station [66 $\left.66^{\circ} 2^{\prime} \mathrm{S} 89^{\circ} 48^{\prime} \mathrm{E}\right]$, Davis Sea, Antarctica.

Material examined: Holotype (ZMB-Moll 63116) and 6 additional lots (see Online Resource 1).

Distribution: South Orkney, South Shetland, Antarctica (Fig. 1a). Living specimens: $38-1180 \mathrm{~m}$ depth.

Description (Fig. 2g-1; Online Resource 2: Fig. 2): Shell large for the genus (maximum $L=5.8 \mathrm{~mm}$ ), inflated $(W / H=0.72 \pm 0.03 ; n=7)$, delicate. Shell outline ovate. Anterodorsal and posterodorsal margins sloping straight; the posterior somewhat longer and sloping less than the anterior one; both forming an angulation at its junction with anterior and posterior margins. Ventral margin somewhat projected behind midline; continuous with anterior and posterior margins; posterior end higher than anterior end. Umbones low but wide, slightly raised from dorsal margin. Prodissoconch of about $720 \mu \mathrm{m} \mathrm{L}$, subcircular; with widely spaced, minute, irregularly distributed granules. Dissoconch whitish; sculptured with 65-75 low and narrow radial ribs and narrow commarginal lines. Periostracum pale yellow.

Escutcheon poorly defined, narrow and elongated. Inner surface of shell whitish; margins finely crenulated. Hinge plate delicate, deeply sinuated below umbo in the right valve. Right valve: anterior cardinal slightly widening towards the distal part; posterior cardinal uniform in diameter, almost a half the size of anterior cardinal. Posterior lateral tooth elongated, narrow and low. Left valve: median cardinal with the anterior side larger than the posterior side; having a deep notch that extends from the base to the cusp, giving the appearance of a bifid tooth. Posterior cardinal short and straight directed towards the posteroventral margin, extending all along 
the hinge plate height; anterior cardinal moderately solid, similar in length to posterior cardinal, anteroventrally directed. Posterior lateral tooth long, moderately solid, merged to posterodorsal margin. Internal ligament extending for one half of the height of the hinge plate. External ligament behind umbones.

Anatomy (Online Resource 2: Fig. 7b): Mantle margin free for about three-fourths of its total length, posteriorly fused, forming a single permanent siphonal opening. About 20 pairs of tentacles distributed along the posterior fused area, and extending over the posterior part of the inhalant-pedal opening. Ctenidia with almost vertical axis. Inner demibranch triangular, with about 40 anteroventrally directed filaments in larger specimens; outer demibranch one-third the size of the inner demibranch, with about 25 filaments.

Remarks: Cyamiocardium rotundatum was previously regarded as a [possible] synonym of C. denticulatum (e.g.,: Soot-Ryen 1951; Dell 1990; Engl 2012). However, the present study reveals that both species are actually different. Cyamiocardium rotundatum strikingly differs from $C$. denticulatum by having a more delicate shell, with lower umbones, the posterodorsal margin with less slope and the ventral margin projected behind midline. The last two characteristics produce a notorious difference in the shell height between anterior and posterior ends in $C$. rotundatum, which is not evident in the case of $C$. denticulatum. In addition, $C$. rotundatum has a greater number of radial ribs than $C$. denticulatum (65-75 vs. 42-44, respectively), being the ribs narrower in C. rotundatum than in C. denticulatum. Another difference is the degree of projection of the hinge plate, a fact particularly noticeable in the right valve by the deeper sinuation of the hinge plate below umbo of $C$. rotundatum.

The specimens figured by Soot-Ryen (1951; Figs. 7, 8), Osorio (1974: Fig. 1a-c, Hain (1990; Fig. 6a, b), ), Absher and Feijó (1998: Fig. 4O) and Aldea and Troncoso (2010: Fig. 239) as C. denticulatum shows the characteristics here recognized as diagnostic for C. rotundatum; consequently, these records are reassigned to this species.

Soot-Ryen (1951) described for C. rotundatum (as C. denticulatum) the presence of an "open mantle" (i.e., lacking of fusions) and the absence of ventral groove in the foot. The material studied herein allows to confirm that the fusion of the posterior part of mantle margin and the ventral groove in the foot are actually present in this species. 
(Figures 1b, 3a-f, 5f-n and 6f-i; Online Resource 2: Figs. 3, 7c, i)

Fig. 3

Cyamiocardium dahli (a-f) and C. chuanisinense new species (g-l), a, c-f specimens from Sloggett Bay, Tierra del Fuego, 15-30 m (MLP-Ma 14505), b one paratype (SMNH 5941), g, h holotype (MACN-In 41423), i-l paratypes (MACN-In 41424), a, $\mathbf{b}, \mathbf{g}$ outer views right valve, $\mathbf{h}$ outer view left valve, $\mathbf{c}, \mathbf{i}$ inner view left valve, $\mathbf{d}, \mathbf{j}$ inner view right valve, $\mathbf{e}, \mathbf{k}$ detail of the prodissoconch sculpture, $\mathbf{f}, \mathbf{I}$ hinge plates (left valve upper, right valve lower). Scale bars $\mathbf{a}-\mathbf{d}, \mathbf{g}-\mathbf{j}: 1 \mathrm{~mm}$; e, k: $20 \mu \mathrm{m} ; \mathbf{f}, \mathbf{l}: 500 \mu \mathrm{m}$ 

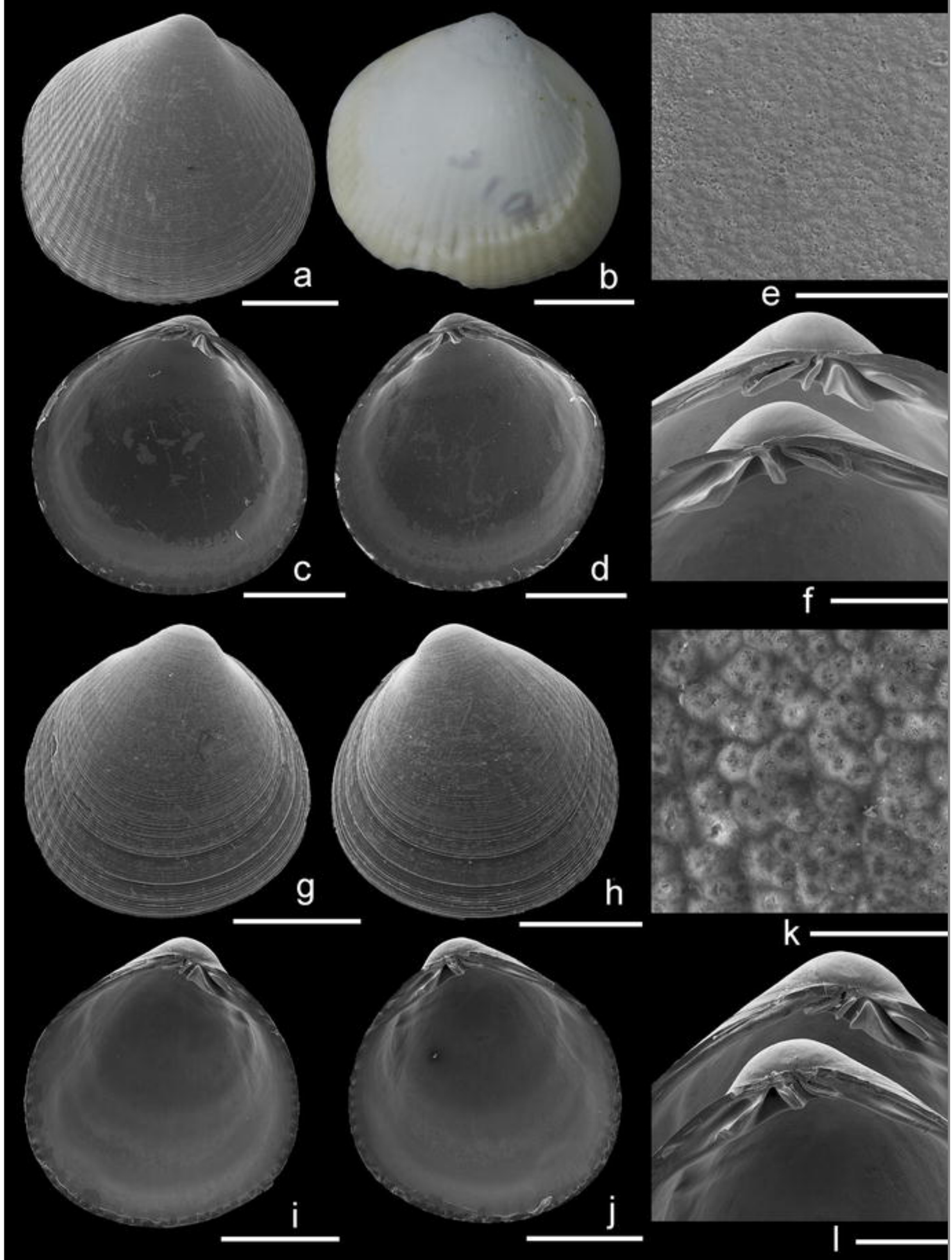
Cyamiocardium dahli Soot-Ryen 1957: 4, Soot-Ryen 1959: 45-46, pl. 2, Fig. 16.

Cyamiocardium denticulatum: Dell 1964: 203-204 [non Smith, 1907; in part]; Dell 1990: 50 [non Smith, 1907; in part].

Type locality: $41^{\circ} 44.17^{\prime} \mathrm{S} 73^{\circ} 15.25^{\prime} \mathrm{W}$, Canal San Antonio, Golfo de Ancud, Chile, $15 \mathrm{~m}$.

Material examined: Holotype (SMNH 3893), 4 paratypes (SMNH 5940, 5941) and 23 additional lots (see Online Resource 1).

Distribution: Golfo de Ancud, Chile to Isla de los Estados (Fig. 1b). Living specimens: 5-30 $\mathrm{m}$ depth.

Description (Fig. 3a-f; Online Resource 2: Fig. 3): Shell medium-sized for the genus (maximum $L=4.7 \mathrm{~mm})$, not inflated $(W / H=0.55 \pm 0.03 ; n=18)$, delicate. Shell outline ovate to subcircular, with the anterior end moderately to markedly projected. Posterodorsal margin long, sloping straight, forming a weak angulosity at the junction with posterior margin. Ventral margin uniformly curved, continuous with posterior and anterior margins; sometime with a weak flattening in the posterior part of ventral margin or in posterior margin. Umbones extremely low but wide, the posterior side appearing as a continuity of the posterodorsal margin of shell. Prodissoconch of about $365 \mu \mathrm{m} \mathrm{L}$, ovate, with irregular, microscopic, closely arranged granules. Dissoconch whitish, porcelaneous; sculptured with 36-40, wide and low radial ribs and narrow commarginal lines. Periostracum yellowish-white, iridescent, with prominent commarginal folds. Escutcheon elongated, narrow, poorly differentiated. Inner surface of shell white, dull; margins finely crenulated. Hinge plate delicate, particularly in the right valve by the deep sinuation below umbo. Right valve: anterior cardinal somewhat distally widened; posterior cardinal a half the size of anterior cardinal. Posterior lateral tooth narrow and elongated. Left valve: median cardinal with the anterior side longer than the posterior one; having a deep sulcus that extends from the base to the cusp, giving the appearance of a bifid tooth; posterior cardinal small, posteroventrally direct; with the distal part extending beyond hinge plate margin; anterior cardinal narrow and elongated, longer than the posterior cardinal, anteriorly directed. Posterior lateral tooth moderate solid merged to the margin. Internal ligament extending for the total height of the hinge plate. External ligament anterior and posterior to umbones.

Anatomy (Fig. 5f-n; Online Resource 2: Fig. 7c, i): Mantle margin with 3 permanent openings: an extensive pedal opening, along the anterior half of animal, 
and two smaller posterior siphonal openings: one inhalant, the other exhalant. Along the pedal opening the three mantle folds are recognizable: outer fold with a short outer element, and a longer, narrow and simple inner element; middle fold elongated, distally bifurcated; inner fold short and stout. In the posterior fused area, fusion involves the inner mantle folds, although well posteriorly, just below the posterior adductor muscle, the middle mantle folds are also involved. Along the posterior fused area, and reaching to the posterior most part of pedal aperture, small tentacles are present. Tentacles arise from the base of inner mantle fold; they have a great development of internal muscular fibers, a fact that determine its great retraction in the fixed material. Only one anterior and one posterior retractor muscles, present. Glandular byssal complex ("byssal gland") very conspicuous, and persistent in adult specimens. Ctenidia with almost vertical axis. Inner demibranch triangular, longer than high; with about 23 anteroventrally directed filaments, in larger specimens; outer demibranch a fourth the size of inner demibranch, with up to 27 filaments. Ascending lamella of inner demibranch approximately three-fourth the height of descending lamella; descending lamellae of outer demibranch approximately one half the height of ascending lamellae. Interfilament and interlamellar junctions present; the former well-developed all along the outer demibranch and free portion of the inner demibranch, although reduced in number in brooding specimens. Ctenidia filaments with well-developed frontal, laterofrontal, and lateral cilia.

Remarks: Soot-Ryen (1959) states that the holotype has "3.6 $\mathrm{mm} \times 3.5 \mathrm{~mm} \times 2.6 \mathrm{~mm}$ " (i.e., length, height, and width, respectively). However, a new measurement of this specimen reveals that the width he indicated is wrong, being the actual value $2.0 \mathrm{~mm}$.

\section{Cyamiocardium crassilabrum Dell, 1964}

(Figures 1b, 41; Online Resource 2: Fig. 7d, j)

\section{Fig. 4}

Cyamiocardium namuncurense new species $(\mathbf{a}-\mathbf{f})$, C. yeskumaala new species $(\mathbf{g}-\mathbf{k})$ and C. crassilabrum (I), a, c, d, f holotype (MLP-Ma 14512), b specimen from $54^{\circ} 25^{\prime} \mathrm{S} 57^{\circ} 32^{\prime} \mathrm{W}$, Burdwood Bank, $102 \mathrm{~m}$ (NMSZ 1921.143.717), e paratype (MLPMa 14511), g paratype (ZMB-Moll 103.539c). h paratype (ZMB-Moll 103.539b), i-k

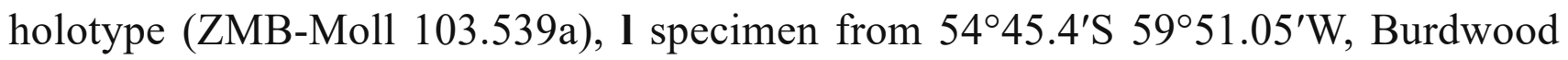
Bank, 174 m (MACN-In 41445), a, g, h outer views right valve, b outer view left valve, c, i inner view left valve, $\mathbf{d}$, $\mathbf{j}$ inner view right valve, e, $\mathbf{l}$ detail of 
prodissoconch sculpture, $\mathbf{f}, \mathbf{k}$ hinge plates (left valve upper, right valve lower). Scale bars $\mathbf{a}-\mathbf{d}, \mathbf{g}-\mathbf{j}: 1 \mathrm{~mm} ; \mathbf{e}, \mathbf{l}: 20 \mu \mathrm{m} ; \mathbf{f}, \mathbf{k}: 500 \mu \mathrm{m}$

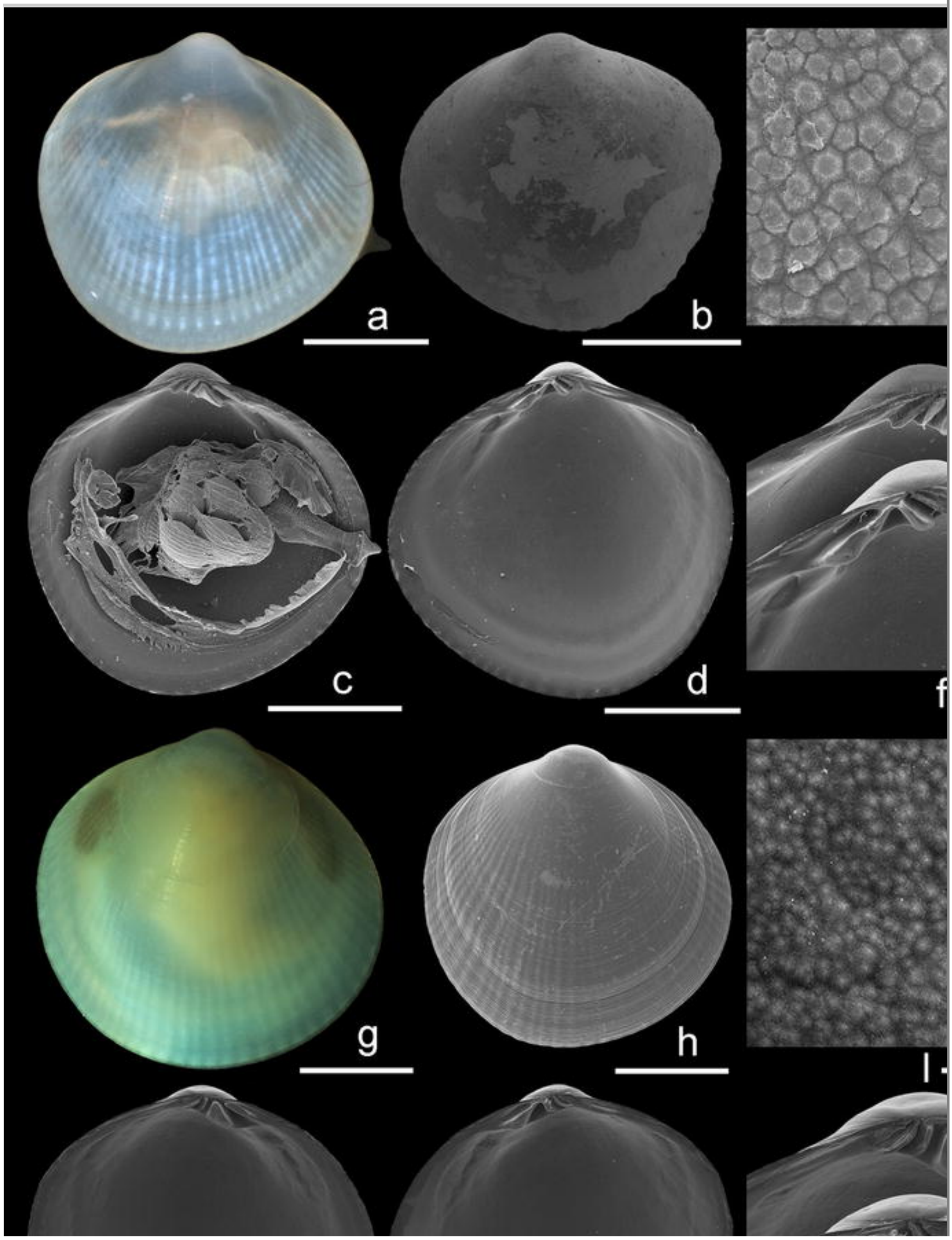




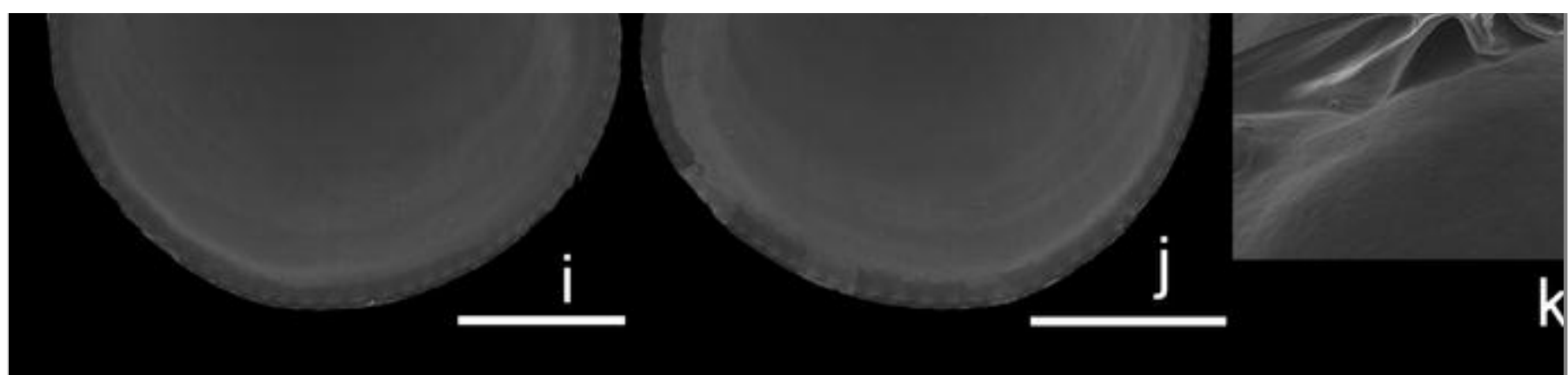

Cyamiocardium crassilabrum Dell 1964: 204, Fig. 4, numbers 1, 2, and pl. 6, Figs. 1, 2; Castellanos 1980: 135.

Perrierina crassilabrum: Zelaya 2008: 52-55.

NOT Cyamiocardium crassilabrum: Absher \& Feijó 1998: 442, Fig. 4P [is $C$. denticulatum].

Material examined: Holotype (NHMUK 1962863), and 1 additional lot from 544․ $4^{\prime} \mathrm{S}$ 5951.05'W, Burdwood Bank, 174 m (MACN-In 41445: 19 spec, $17 \mathrm{v}$ ).

Anatomy (Online Resource 2: Fig. 7d, j): Mantle margin free for about one half its total length; posterior half fused delimiting two permanent siphonal opening. Along the fused area about 24 pairs of tentacles. Parallel to these rows, more internally, a second row of four tentacles appears just posterior to the inhalant aperture. The inhalant aperture also bears 4 additional pairs of tentacles at its anterior margin. Ctenidia with axis almost vertical. Inner demibranch trapezoidal, slightly higher than longer, with about 50, anteroventrally directed filaments; outer demibranch one half the size of inner demibranch, with up to 40 filaments. Ascending lamellae of inner demibranch approximately one half the height of descending lamellae; descending lamellae of outer demibranch three-fourth the height of ascending lamellae.

Remarks: Zelaya (2008) redescribed and figured the shell morphology of $C$. crassilabrum, thus considering unnecessary to redescribe it herein. The prodissoconch of this species was described as smooth by Zelaya (2008). This is true when viewed under low magnification; however, microscopic, contiguous granules are evident when viewed at higher magnification (Fig. 4l).

The hinge of this species (properly figured by Zelaya 2008: Figs. 10,11) closely resembles that of other species of Cyamiocardium, except by having two series of tubercles (one anterior and the other posterior to the umbones), which produce a 
taxodont appearance. The comparison of this hinge plate morphology with the figure of Perrierina taxodonta provided by Lamy (1917, p. 263), conducted to Zelaya (2008) to propose a reallocation for C. crassilabrum into Perrierina.

However, the study of a lot of $P$. taxodonta (USNM 679955), the type species of the genus, allows to confirm that such placement is inadequate. Based on the current revision of Cyamiocardium, the species is newly reallocated under this genus. The anatomical characters for the species supports this generic placement.

The specimen figured by Absher and Feijó (1998, Fig. 4P) as C. crassilabrum does not correspond actually to this species. Instead, it shows the characteristics here recognized as distinctive for $C$. denticulatum.

\section{Cyamiocardium chuanisinense new species}

(Figures 1b, 3g-1,5d, e, and 6b-e; Online Resource 2: Figs. 4, 7e, k)

\section{Fig. 5}

Gross anatomy of a hexamethyldisilazane prepared specimen $(\mathbf{a}-\mathbf{c})$, detail of byssal filament (d) and histological sections (e-n). a-c Cyamiocardium denticulatum. d, e $C$. chuanisinense new species. $\mathbf{f}-\mathbf{n} C$. dahli, a posterior view, $\mathbf{b}$ detail of the posterior part of mantle margin, at the site of fusion of mantle folds, $\mathbf{c}$ detail of the tentacles, $\mathbf{d}$ foot in right side view, $\mathbf{e}, \mathbf{h}$ detail of mantle folds at pedal opening, $\mathbf{f}, \mathbf{g}$ foot in cross (f) and sagittal (g) sections. i detail of fusion of mantle folds between siphonal openings. $\mathbf{j}$ detail of fusion of mantle folds just below the posterior adductor muscle, $\mathbf{k}-\mathbf{n}$ inner demibranch of a male $(\mathbf{k}, \mathbf{l})$ and a female with uncleaved eggs $(\mathbf{m}, \mathbf{n})$. Scale bars d: 1 mm; a, e: $500 \mu \mathrm{m} ; \mathbf{b}, \mathbf{f}, \mathbf{g}, \mathbf{k}: 200 \mu \mathrm{m} ; \mathbf{h}-\mathbf{j}, \mathbf{m}: 100 \mu \mathrm{m} ; \mathbf{c}, \mathbf{l}, \mathbf{n}: 50 \mu \mathrm{m}$. al ascending lamellae, arm anterior retractor muscle, $b f$ byssal filament, $d l$ descending lamellae, eo exhalant opening, $f$ foot, $f c$ frontal cilia, $g b c$ glandular byssal complex, ifj interfilament junction, ilj interlamellar junction, imf inner mantle fold, ipo inhalantpedal opening, $l c$ lateral cilia, $l f c$ latero-frontal cilia, $m f$ mantle folds, $m g$ male gonad, mmf middle mantle fold, omf outer mantle fold, prm posterior retractor muscle, $t$ tentacles, ue uncleaved egg, $v g$ ventral groove

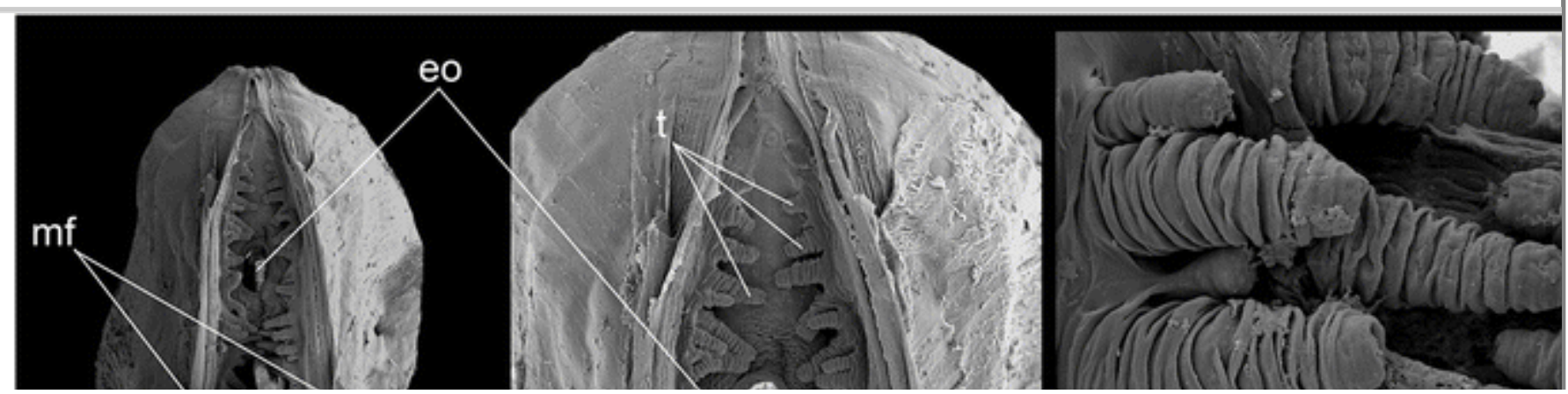



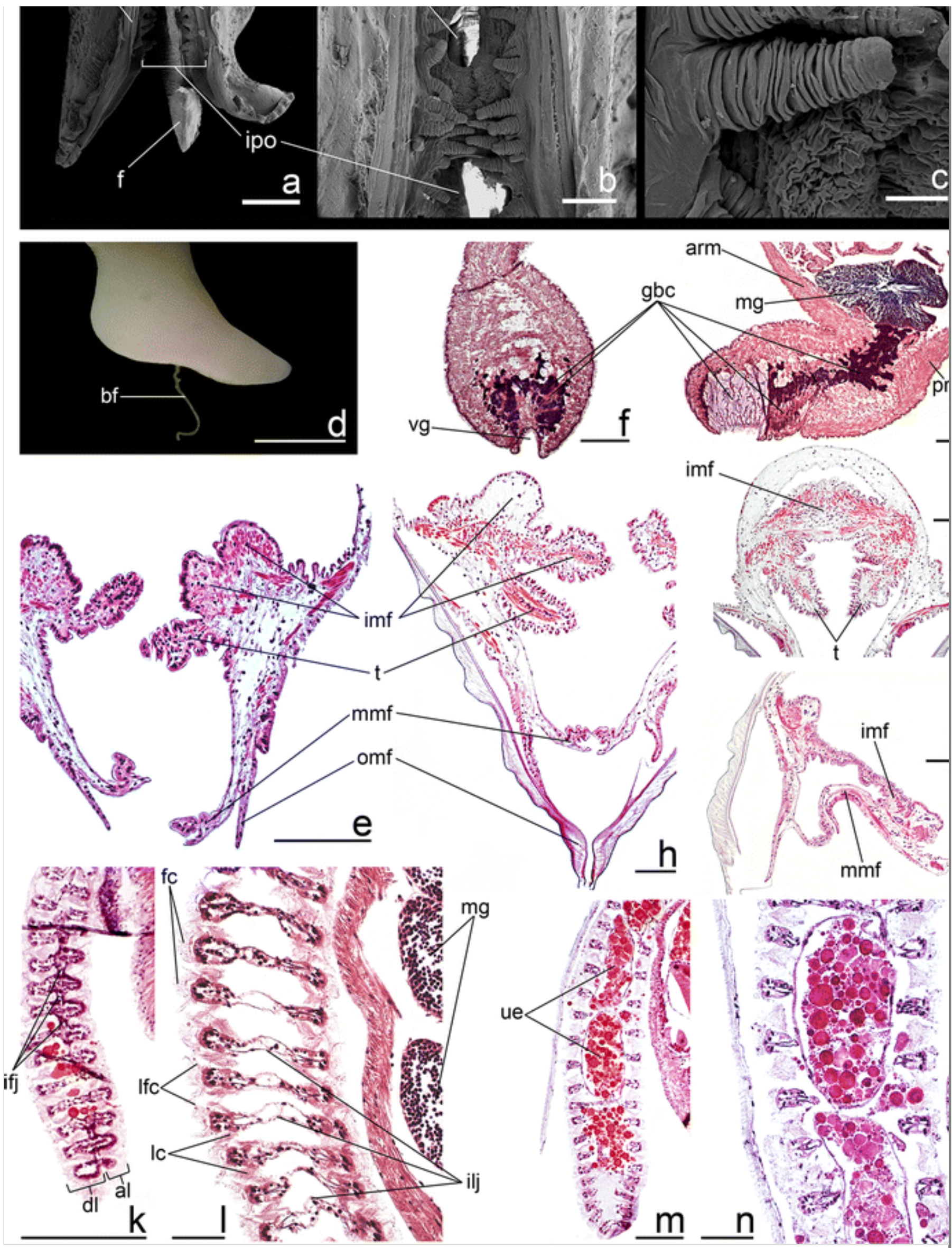

imf
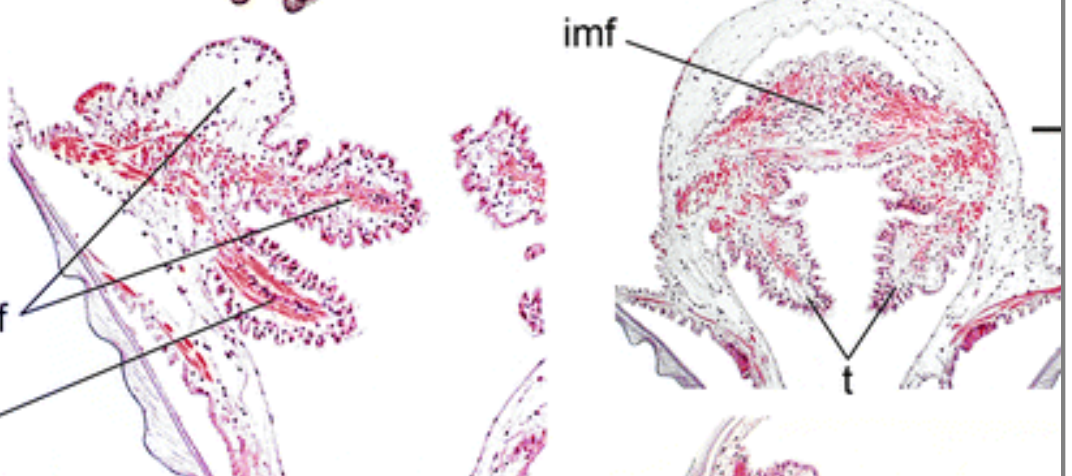
Histological sections of oocytes and embryos. a Cyamiocardium denticulatum. b-e $C$. chuanisinense new species. $\mathbf{f}-\mathbf{i} C$. dahli. a, $\mathbf{c}, \mathbf{e}, \mathbf{h}, \mathbf{i}$ uncleaved egg and embryos fixed to the ctenidia, b vitellogenic oocyte, fixed to the acinus wall, d, f previtellogenic oocytes, fixed to the acinus wall, $\mathbf{g}$ early vitellogenic oocyte with associated follicular cells. Scale bars a-d, f, g, i $50 \mu \mathrm{m}$; e $200 \mu \mathrm{m}$; h $100 \mu \mathrm{m} . f_{c}$ follicular cell, id inner demibranch, od outer demibranch 


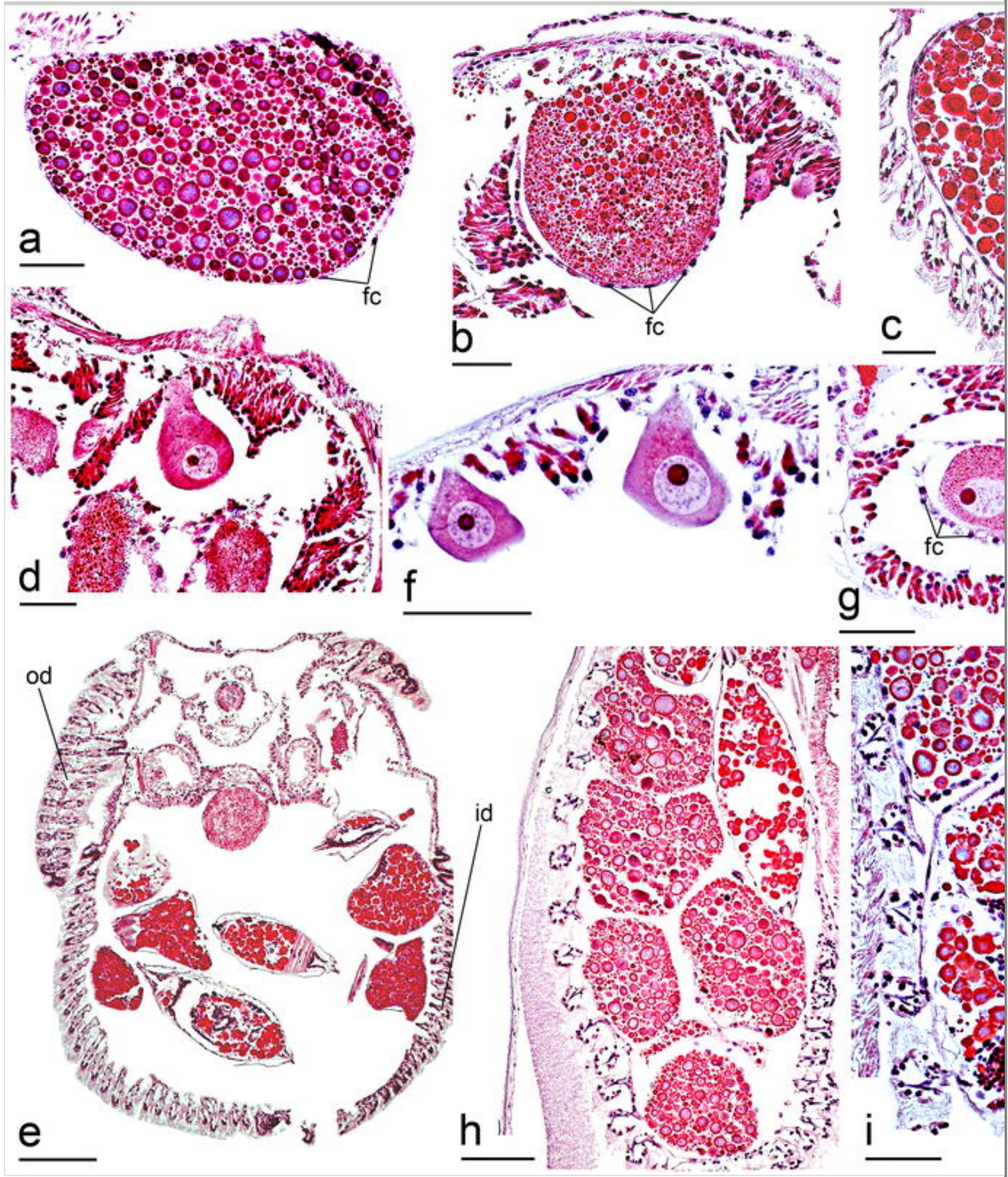

Cyamiocardium denticulatum: Dell 1964: 203-204 [non Smith, 1907; in part]; Dell 1990: 50 [non Smith, 1907; in part].

Type locality: $54^{\circ} 51^{\prime} \mathrm{S} 64^{\circ} 30^{\prime} \mathrm{W}$, Bahía Cánepa, Isla de los Estados, $60 \mathrm{~m}$. 
Type material: Holotype (MACN-In 41423) and 45 paratypes from the type locality (29 paratypes MACN-In 41424; 16 paratypes MLP-Ma 14510).

Zoobank registration number: EC4B9561-EAAA-4E65-ABAD-E1C992CEF4A2.

Other material examined: 12 lots (see Online Resource 1).

Distribution: Tierra del Fuego and Isla de los Estados (Fig. 1b). Living specimens: $10-80 \mathrm{~m}$ depth.

Etymology: "Chuanisin" is the name used by the Yagan (one of the local indigenous populations) to refer to the Isla de los Estados, the type locality for the species.

Diagnosis: Shell subquadrate, inflated, moderately solid. Umbones prominent, high and wide; prodissoconch sculptured with microscopic contiguous granules. Dissoconch with 25-35 low and wide radial ribs. Hinge plate solid.

Description (Fig. 3g-1; Online Resource 2: Fig. 4): Shell small for the genus (maximum $L=3.8 \mathrm{~mm})$, inflated $(W / H=0.66 \pm 0.06 ; n=18)$, moderately solid. Shell outline subquadrate, with the posterior end projected and the anterior end abbreviated. Anterodorsal margin convex, descending abruptly. Ventral margin evenly curved, continuous with anterior and posterior margins. Posterodorsal margin long, sloping abruptly, straight, forming an angulation at the junction with posterior margin. Umbones prominent, high and wide; the posterior side appearing as a continuity of dorsal margin of shell. Prodissoconch of about $380 \mu \mathrm{m} \mathrm{L}$, ovate, sculptured with microscopic, contiguous granules. Dissoconch white, porcelaneous, sculptured with 25-35 moderately low and wide radial ribs. In addition, narrow and closely spaced commarginal lines, present. Periostracum pink-orange, iridescent, with prominent commarginal folds. Escutcheon ill-defined. Inner surface white, dull; with strongly crenulated margins. Hinge plate solid, slightly sinuated below the umbo in the right valve. Right valve: anterior cardinal long; posterior cardinal one half the size of anterior cardinal. Posterior lateral tooth elongated and narrow. Left valve: median cardinal large and strong; triangular in outline, with the anterior side longer than the posterior one; a deep sulcus running from the base to the cusp giving a bifid appearance to the tooth; posterior cardinal small, posteroventrally directed; anterior cardinal narrow and elongated, longer than the posterior cardinal, anteriorly directed. Posterior lateral tooth only represented by a thickening of shell margin. Internal ligament extending along all hinge plate. External ligament anterior and posterior to umbones. 
Anatomy (Fig. 5d, e; Online Resource 2: Fig. 7e, k): Mantle margin largely free for about two-third of its total length, posteriorly fused, delimiting two small, permanent siphonal openings. Along the pedal aperture, the three mantle lobes are clearly recognizable: outer fold with a short outer element, and a longer, narrow and simple inner element; middle fold elongated, distally bifurcated; inner fold short and stout. Posterior fusion involving inner mantle fold. Along the posterior fused area, and reaching to the posteriormost part of pedal aperture, small tentacles are present. Tentacles arranged in two rows, comprising 10 pairs between the posterior end and the exhalant opening, 10 pairs between inhalant and exhalant openings, and 5 pairs tentacles between inhalant and pedal openings; the latter two areas showing a second, more internal row of tentacles, parallel to the previous one.

Foot secreting a byssal filament, composed by a single, narrow thread-observed. Ctenidia with almost vertical axis. Inner demibranch triangular, as high as long, with about 27 anteroventrally directed filaments in larger specimens; outer demibranch one-third the size of inner demibranch, with up to 29 filaments. Ascending lamellae of inner demibranch approximately one-third the height of descending lamellae; descending lamellae of outer demibranch one half the height of ascending lamellae.

Remarks: Cyamiocardium chuanisinense closely resembles $C$. dahli, from which it differs by having a heavier and more inflated shell ( $W / H=0.66$ vs. 0.55 , respectively), with the anterior end shorter, the umbones wider and higher, and the escutcheon ill-defined. The periostracum is pink-orange in C. chuanisinense, and yellowish-white in $C$. dahli. The hinge plate completely contains the cardinal teeth in C. chuanisinense, while in C. dahli the distal part of the teeth extends beyond hinge plate margin. In addition, the internal ligament is considerably longer in $C$. dahli than $C$. chuanisinense. Other differences arise in the inner demibranch, which in $C$. chuanisinense is as long as high, while in $C$. dahli it is longer than high, with the ascending lamellae considerably shorter in C. chuanisinense than in C. dahli.

Cyamiocardium chuanisinense is also similar to $C$. domaneschii, differing by the presence of a more solid, non-translucent shell, with shorter anterior end, and stronger hinge plate.

Dell $(1964,1990)$ mentioned the presence of $C$. denticulatum from the Strait of Magellan, Tierra del Fuego, Cape Horn and Isla de los Estados, although some of the specimens from these localities actually correspond to C. dahli, C. chuanisinense new species and $C$. yeskumaala new species. 
Cyamiocardium namuncurense new species

(Figures 1b, 4a-f; Online Resource 2: Figs. 5, 7f, 1)

Cyamium denticulatum: Melvill \& Standen 1912: 137 [non Smith, 1907].

Type locality: $54^{\circ} 01.36^{\prime} \mathrm{S} 62^{\circ} 01.33^{\prime} \mathrm{W}$, Burdwood Bank, $272 \mathrm{~m}$.

Type material: Holotype (MLP-Ma 14512) and 28 paratypes from the type locality (16 paratypes MACN-In 41425; 12 paratypes MLP-Ma 14511).

Zoobank registration number: 7DB6391F-F0DD-4E90-8AC0-51C838263517.

Other material examined: 4 lots (see Online Resource 1).

Distribution: Thus far only know from the Burdwood Bank (Fig. 1b). Living specimens: 122-272 m depth.

Etymology: The species is named after the Marine Protected Area

"Namuncurá/Burdwood Bank," the place where this species was found in greater abundance.

Diagnosis: Shell rhomboidal, somewhat inflated, delicate. Posterior end higher than anterior end. Prodissoconch sculptured with microscopic polyhedral granules. Dissoconch with 38-40 low and wide radial ribs. Hinge plate delicate.

Description (Fig. 4a-f; Online Resource 2: Fig. 5): Shell large for the genus (maximum $L: 5.1 \mathrm{~mm})$, somewhat inflated $(W / H=0.61 \pm 0.04 ; n=18)$, thin. Shell outline rhomboidal, with the anterior end bluntly pointed and the posterior end obliquely truncated, higher than the anterior one. Ventral margin markedly projected behind midline; anterior part forming a closed curve, continues with the anterior and anterodorsal margins; posterior part forming a broad arch with posterior margin. Posterodorsal margin long, sloping straight, forming a weak angulation at the junction with posterior margin. Umbones low but wide. Prodissoconch of about $360 \mu \mathrm{m} \mathrm{L}$, ovate, with conspicuous, polyhedral, closely arranged microscopic granules. Dissoconch translucent; sculptured with about 4143 low and wide radial ribs and narrow commarginal lines. Periostracum pale yellow, with prominent commarginal folds. Escutcheon poorly differentiated. Inner surface of shell translucent; margins crenulated. Hinge plate delicate, deeply sinuated below the umbo in the right valve. Right valve: anterior cardinal slightly 
enlarged distally; posterior cardinal about one-third the length of anterior. Posterior lateral tooth elongated, moderately solid. Left valve: median cardinal large but delicate, triangular in outline, with the anterior side longer than the posterior one; anterior and posterior cardinal teeth elongated and thin; anterior twice as long as posterior. Anterior cardinal anteroventrally directed; posterior posteroventrally directed. Posterior lateral tooth well-marked, close to dorsal margin. Internal ligament extending along all the hinge plate. External ligament posterior to umbones and between prodissoconchs.

Anatomy (Online Resource 2: Fig. 7f, 1): Anterior half of mantle margin free, forming a large pedal opening; posterior half fused, delimiting two smaller permanent siphonal openings. Along the fused area, two rows of tentacles arranged discontinuously: 6 pairs between the posterior adductor muscle and exhalant opening, 6 pairs between inhalant and exhalant openings, and 6 pairs along the inhalant opening. The latter also has 4 pairs of additional tentacles along its anterior margin. Ctenidia with almost vertical axis. Inner demibranch subquadrate; with about 50 anteroventrally directed filaments in larger specimens; outer demibranch one-third the size of inner demibranch, with up to 40 filaments. Ascending lamellae of inner demibranch approximately one half the height of descending lamellae; descending lamellae of outer demibranch three-fourth the height of ascending lamellae.

Remarks: Cyamiocardium namuncurense closely resembles in shell outline $C$. rotundatum, from which it differs by being translucent, with the shell less inflated, and the anterodorsal margin continuous with the anterior margin. Another difference arises in the dissoconch sculpture: $C$. namuncurense has a minor number of radial ribs, which in addition are wider than those of $C$. rotundatum.

Furthermore, the prodissoconch of $C$. namuncurense is smaller than that of $C$. rotundatum (360 vs. $720 \mu \mathrm{m})$, and sculptured with closely arranged microscopic polyhedral granules, instead of isolated, rounded granules, as present in $C$.

rotundatum. Anatomically, the main difference between these two species arises in the number of posterior fusions, which determine the presence of two permanent siphonal openings in $C$. namuncurense and only one in $C$. rotundatum. Another species similar to $C$. namuncurense is $C$. yeskumaala (see comparison under that species).

Melvill and Standen (1912) identified as C. denticulatum specimens collected at the Burdwood Bank. The study of this material (NHSZ 1921.143.717; Fig. 5b) reveals that these specimens actually correspond to C. namuncurense. 
Cyamiocardium yeskumaala new species

(Figures 1b, 4g-k; Online Resource 2: Figs. 6, 7 g, m)

Cyamiocardium denticulatum: Dell 1964: 203-204 [non Smith, 1907; in part]; Dell 1990: 50 [non Smith, 1907; in part]; Linse 2002: 59 [non Smith, 1907].

Type locality: $55^{\circ} 44.2^{\prime} \mathrm{S} 66^{\circ} 14.9^{\prime} \mathrm{W}$, Cape Horn, $428 \mathrm{~m}$.

Type material: Holotype (ZMB-Moll 103.539a) and 13 paratypes from the type locality (3 paratypes ZMB-Moll 103.539b; 10 paratypes ZMB-Moll 103.539c).

Zoobank registration number: B8892D45-BDC7-4846-AF7E-DC32D7702332.

Material examined: 3 lots (see Online Resource 1).

Distribution: Strait of Magellan and Cape Horn (Fig. 1b). Living specimens: 188$428 \mathrm{~m}$ depth.

Etymology: The name of the species refers to the indigenous group that inhabited the Cape Horn archipelago.

Diagnosis: Shell subcircular to subovate, somewhat inflated, delicate. Anterior end as high as posterior end. Umbones low and wide; prodissoconch smooth under high magnification. Dissoconch sculptured with 44-47 low and narrow radial ribs. Hinge plate solid.

Description (Fig. 4g-k; Online Resource 2: Fig. 6): Shell medium-sized for the genus (maximum $L=4.55 \mathrm{~mm}$ ), somewhat inflated $(W / H=0.62 \pm 0.03 ; n=4$ ), delicate. Shell outline subcircular to subovate. Larger specimens with evenly curved ventral margin forming a continuous curve with anterior and posterior margins; smaller specimens with the ventral margin slightly expanded behind midline; the anterior part forming a continuous, close curve with anterior margin, and the posterior part forming a wide, oblique curve with posterior margin. Anterior part of dorsal margin extremely short, sloping slow and straight; forming a marked angulation at its junction with anterior margin. Posterior end as high as anterior end. Posterodorsal margin long, sloping straight, forming a weak angulation in the junction with posterior margin. Umbones low but wide. Prodissoconch of about $470 \mu \mathrm{m}$ L, rounded, smooth, even at high magnification. Dissoconch translucent, sculptured with 44-47 low and narrow radial ribs and narrow commarginal lines. 
Periostracum thick, yellow-olivaceous, forming prominent commarginal folds. Escutcheon poorly differentiated. Inner surface of shell yellowish; margins finely crenulated. Hinge plate solid, slightly sinuated below the umbo in the right valve. Right valve: anterior cardinal elongated distally widening; posterior cardinal one half the size of anterior one. Posterior lateral tooth elongated. Left valve: median cardinal large and strong, relatively high, triangular in outline, with the anterior side longer than the posterior one; anterior and posterior cardinal teeth narrow, elongated, similar in length; posterior posteroventrally directed; anterior anteroventrally directed. Posterior lateral tooth moderately solid close to dorsal margin. Internal ligament extending along all hinge plate. External ligament anterior and posterior to umbones.

Anatomy (Online Resource 2: Fig. 7 g, m): Mantle margin free in its anterior half, posteriorly fused, delimiting two permanent siphonal openings. Along the fused area, two rows of tentacles are present.

Ctenidia with almost vertical axis. Inner demibranch triangular, as high as long, with about 35 anteroventrally directed filaments in larger specimens; outer demibranch one-third the size of inner demibranch, with about 30 filaments. Ascending lamellae of inner demibranch approximately three-fourth the height of descending lamellae; descending lamellae of outer demibranch one half the height of ascending lamellae.

Remarks: In general shell outline $C$. yeskumaala resembles $C$. namuncurense and $C$. rotundatum, from which it differs by having the ventral margin less markedly projected behind the midline. Another distinctive character is the prodissoconch sculpture: in C. yeskumaala it is smooth, while in C. namuncurense and $C$. rotundatum it is microscopically sculptured with granules. In C. yeskumaala the hinge plate is strong, containing completely the cardinal teeth, while in $C$. namuncurense and $C$. rotundatum the distal part of cardinal teeth extends beyond the hinge plate margin. Furthermore, the internal ligament of $C$. yeskumaala is long, such as in $C$. namuncurense, and this contrasts with the short ligament present in $C$. rotundatum. The latter also differs by reaching a greater size, and by having a larger prodissoconch.

Cyamiocardium yeskumaala differs from $C$. dahli and C. chuanisinense in the size and sculpture of the prodissoconch: medium and smooth in C. yeskumaala vs. small and microscopically sculptured with granules in $C$. dahli and C. chuanisinense. In addition, the dissoconch is translucent in C. yeskumaala while it is whitish and porcelaneous in C. dahli and C. chuanisinense. 
Linse (2002) mentioned $C$. denticulatum from the Drake Passage and Cape Horn, although the study of these specimens (housed at the ZMB) reveals they actually correspond to C. yeskumaala.

\section{Reproductive traits}

Several coincidences in the reproductive traits were observed in the four species histologically studied:

- All the specimens were either males (Fig. 51) or females (Fig. 5m, n), with none specimens showing signals of hermaphroditism. [add a tabulation as for the following items]

- Gonads, located dorsally in the visceral mass, were arranged in acini. Oocytes originate in the wall of the female acini, where they remain united, by means of a projection of its cytoplasm, during its first instances of development (Fig. 6d, $\mathrm{f}, \mathrm{g})$; then they are released to the lumen of the acini.

- During the onset of growth and the beginning of the vitellogenesis process, a continuous layer of follicular cell is formed around each oocyte. Such cells are present during all the vitellogenesis process (Fig. 6a-c, g).

- Once the oocytes are fertilized (the site of fertilization was not observed), the embryos are retained by the maternal individual in the inner demibranch, where they remain until their development is completed (i.e., there are parental cares) (Fig. 6a, c, e, h, i).

- Embryos are arranged in one or two rows per demibranch, and embryos of different degrees of development were observed coexisting in the same maternal individual (Fig. 6e, h).

- Each embryo appears completely surrounded by a layer of follicular cells, which project in a point, forming a fixation structure of the embryo to the ctenidium (i.e., a "stalk"). This tissue remains present until embryos are completely developed.

- Once the development is completed, embryos appear free in the suprabranchial chamber until being released.

- Specimens that are incubating their offspring in the ctenidia, simultaneously 
have in the gonad another series of oocytes.

\section{Discussion}

Since formally proposed by Soot-Ryen (1951), and for more than 50 years, the genus Cyamiocardium remained represented by only three species: $C$. denticulatum (with $C$. rotundatum as a synonym), $C$. dahli, and $C$. crassilabrum. More recently, Passos and Machado (2014) described an additional species (C. domaneschii), and Zelaya (2008) removed C. crassilabrum from this genus, alternatively placing it into Perrierina. As part of the present study, the concept of $C$. denticulatum (the type species) was clarified, resulting in the revalidation of $C$. rotundatum as a full species. In addition, $C$. crassilabrum was confirmed to be actually a member of this genus, and not of Perrierina. Furthermore, three new species of Cyamiocardium were recognized and are described herein: $C$. chuanisinense, $C$. namuncurense, and C. yeskumaala. These new findings resulted in the doubling of the number of species of Cyamiocardium currently known worldwide, making evident the scarce attention that this small-sized group of molluscs received in the past. In this regard, it is interesting to note that material of one of the new species described herein, $C$. namuncurense, had been already collected by the Scottish National Antarctic Expedition (1902-1904), and remained wrongly identified for more than 100 years; and that material of the other two new species described herein has been also previously collected and misidentified.

\section{Useful characters for distinguishing the species}

All the species recognized in this study can be clearly differentiated by their shell morphology. Shells vary from delicate (in C. rotundatum, C. namuncurense, $C$. yeskumaala, and $C$. dahli) to markedly solid (C. denticulatum and $C$. chuanisinense); flat ( $C$. dahli) to inflated ( $C$. denticulatum, $C$. rotundatum, and $C$. chuanisinense); with the shell outline ovate (C. rotundatum), ovate to subcircular (C. dahli and C. yeskumaala), ovate to subquadrate (C. denticulatum), subquadrate (C. chuanisinense) or rhomboidal (C. namuncurense). Other character useful for distinguishing the species is the prodissoconch: it may be large (in C. denticulatum and $C$. rotundatum), small (in C. dahli, C. chuanisinense and C. namuncurense) or medium in size (in C. yeskumaala); completely smooth (in C. yeskumaala) or microscopically sculptured with granules, in the last case being those granules either closely arranged (in C. dahli, C. chuanisinense and C. namuncurense) or widely separated (C. denticulatum and $C$. rotundatum). Anatomically, species vary in the number of posterior (permanent) siphonal openings: one (in C. denticulatum 
and $C$. rotundatum) or two (in all other species); the extension of the posterior row of tentacles: restricted to the posterior fused area, where inhalant and exhalant openings appear (in C. dahli, C. chuanisinense, C. namuncurense, and C.

yeskumaala), or extending anteriorly, being also present at the posteriormost part of the inhalant-pedal opening (in C. denticulatum and C. rotundatum); and the degree of development of the ascending lamella of the inner demibranch which, at its midpoint, may vary from one-third (in $C$. chuanisinense) to three-fourths (in $C$. dahli and C. yeskumaala) of the height of the descending lamellae.

\section{Concerning mantle margin apertures}

As described above, the mantle margin of Cyamiocardium may have one or two permanent siphonal openings posterior to the pedal opening. At first, such variation could appear as surprising within a single genus. However, the observation of living specimens of Cyamiocardium rotundatum (a species having a single permanent siphonal opening) reveals that a second siphonal opening forms temporarily in the posterior part of the "pedal" aperture (i.e., the area flanked by tentacles). This fact reveals that "functionally" Cyamiocardium species have two posterior siphonal openings. A similar variable number of mantle margin openings, as a consequence of the presence of temporal/permanent fusions, has been also reported in other bivalve genus (e.g.,: Ituarte 2007: Pisidium).

\section{Geographical distribution of species of Cyamiocardium}

To date, the genus Cyamiocardium appears restricted to sub-Antarctic and Antarctic waters, with two species ( $C$. denticulatum and $C$. rotundatum) occurring around the Antarctica and in the Scotia Arc islands (south of the Antarctic Convergence), and all the remaining species present at the north of the Antarctic Convergence. Among the last group-of species, five species ( $C$. dahli, C. crassilabrum, C. chuanisinense, C. namuncurense, and C. yeskumaala) occur at the southern tip of south America, either at the Atlantic and Pacific sectors; but one species (C. domaneschii) appears northwards at south of Brazil, associated to sub-Antarctic/Antarctic waters that reach this area.

\section{Comparison of Cyamiocardium with other cyamiid genera}

Cyamiidae appears at present as a poorly known family of bivalves. In fact, there is no consensus, among different authors, on which are the genera to be included therein. Gofas (2010) reported under this family the genera Cyamium Philippi, 1845, Cyamiocardium Soot-Ryen, 1951, Cyamiomactra Bernard, 1897, 
Eugaimardia Cotton, 1931, Kidderia Dall, 1876, Legrandina Tate \& May, 1901, Peregrinamor Shôji, 1938, Perrierina Bernard, 1897, Ptychocardia Thiele, 1912, and Reloncavia Soot-Ryen, 1969. Zelaya and Ituarte (2009), Huber (2010) and Engl (2012) also listed under Cyamiidae the genera Pseudokellya Pelseneer, 1903, Gaimardia Gould, 1852 and Callocardia Adams, 1864, respectively. The inclusion of Callocardia was based on Calliocardia laevis Pelseneer, 1903, a species that according to Allen (2001) actually corresponds to Kelliella Sars, 1870 (Kelliellidae). Gaimardia was also regarded as belonging to a different family (Gaimardiidae) by Morton (1979) and Combosch et al. (2016); and Peregrinamor was included under Montacutidae by Kato and Itani (1995) and Kil and Park (2009). The placement of Peregrinamor in a different superfamily (Galeommatoidea) is ratified in the molecular phylogeny of Goto et al. (2012). With the only exception of Pseudokellya (recently revised by Zelaya and Ituarte, 2009) none of the above-mentioned genera appears properly defined. It is out of the scope of this paper to redescribe/redefine these genera; instead, the subsequent discussion has the only purpose of distinguishing Cyamiocardium from them. For that, the type species of these genera are considered (except otherwise be indicated). In general shell morphology, Cyamiocardium closely resemble Pseudokellya, from which it differs in some aspects of the hinge: in Pseudokellya the hinge plate is only developed anterior to the umbones, the internal ligament is minute, the right valve has an extremely reduced posterior cardinal tooth, and the left valve has only two cardinal teeth (anterior and median), being the median cardinal elongated. In Cyamiocardium, instead, the hinge plate is developed both anterior and posterior to umbones, the internal ligament is elongated and extends for most/all hinge plate height, the right valve has a well-developed posterior cardinal, and the left valve has 3 cardinal teeth, being the median cardinal triangular in outline. In hinge plate morphology Cyamiocardium is more similar to Cyamium, Cyamiomactra, and Perrierina (Ponder 1971 and Huber 2010 regarded Legrandina as a synonym of the latter). Despite this similarity, Cyamium lacks of lateral teeth, Perrierina has several elongated "crests," both anterior and posterior to the umbones, along the dorsal margin (to as lateral teeth by Powell 1979) and Cyamiomactra has an elongated anterior and another posterior lateral tooth in the right valve, that form with the dorsal margin depressions, where the anterior and posterior lateral teeth of the left valve fit. In addition, Cyamium has a considerably more elongated shell than Cyamiocardium. Anatomically, Cyamiocardium is extremely similar to Pseudokellya frankii Zelaya and Ituarte, 2009, only differing in the fact that the anterior and posterior adductor muscles in cross section are similar in size. Ponder (1971) described the gross anatomy of Cyamium, Cyamiomactra and Perrierina, which are also mostly coincident with that of Cyamiocardium. The main differences 
with these genera are: Cyamium lacks the heel in the foot and has a shorter byssal groove; Cyamiomactra has a shorter pedal aperture, restricted to the anterior part of the mantle margin; and Perrierina lacks of byssal groove and posterior tentacles along the fused area of the mantle margin. Gaimardia, Eugaimardia and Kidderia strikingly differ from Cyamiocardium both in shell and hinge plate morphology; they also differ in their mode of life: all these genera live permanently byssated to algae (Gaimardia and Eugaimardia) or rocky substrates (Kidderia). The reproductive characteristics here described for Cyamiocardium are in agreement with that described by Passos and Machado (2014) for C. domaneschii, and are also coincident with that described by Pelseneer (1903) and Zelaya and Ituarte (2009) for Pseudokellya cardiformis and $P$. frankii, respectively. This includes the peculiar formation of a follicular epithelium that completely surrounds the oocytes and embryos throughout the development, and that allows the "anchoring" of the embryos to the ctenidium of the maternal individual. This is certainly an unusual character for bivalves. If Cyamiocardium and Pseudokellya belong to a single family, then it could be expected that this condition has been developed only once. But if Cyamiocardium and Pseudokellya are members of two different families, that imply that the character should appears twice among bivalves. To determine which of them is the correct hypothesis remains as an open question.

\section{Acknowledgements}

The authors specially thank Carolina Romero, Daniel Nahabedian and Jesús Troncoso for kindly making available some of the specimens reported herein; Anna Persson (SMNH) and Andreia Salvador (NHMUK) for the photographs and additional information on the types of C. dahli, C. crassilabrum, and $C$. denticulatum; Lindsey Groves for sending on loan some material housed at the LACM; and Ellen Strong (USNM) and Frank Koeler (formerly ZMB) for their hospitality during the visit of DGZ to their museums. MRU is also grateful to Cristián Ituarte (MACN) for teaching the histological techniques used herein. This study was partially supported by UBACYT 20020150100195BA. MRU is a doctoral fellow at the University of Buenos Aires, and DGZ is member of the Consejo Nacional de Investigaciones Científicas y Técnicas (CONICET), Argentina.

\section{Electronic supplementary material}


Below is the link to the electronic supplementary material.

Supplementary material 1 (PDF 65 kb) Supplementary material 2 (PDF 1712 kb)

\section{References}

Absher TM, Feijó AR (1998) Morphology and ecology of bivalve molluscs from Admiralty Bay, King George Island, Antarctica. Braz Arch Biol Technol 41:437-446

Aldea C, Troncoso JS (2010) Moluscos del Mar de Bellingshausen (Antártica). Troncoso and Aldea (eds), Vigo

Allen JA (2001) The family Kelliellidae (Bivalvia: Heterodonta) from the deep Atlantic and its relationship with the family Vesicomyidae. Zool J Linn SocLond 131:199-226

Combosch DJ, Collins TM, Glover EA, Graf DL, Harper EM, Healy JM, Kawauchi GY, Lemer S, McIntyre E, Strong EE, Taylor JD, Zardus JD, Mikkelsen PM, Giribet G, Bieler R (2016) A family-level tree of Life for bivalves based on a Sanger-sequencing approach. Mol Phylogenet Evol 107:191-208

de Castellanos ZA (1980) Micromoluscos poco conocidos del sur argentinochileno. Neotrópica 25:133-140

Dell RK (1964) Antarctic and sub-Antarctic Mollusca: Amphineura, Scaphopoda and Bivalvia. Discov Rep 33:93-250

Dell RK (1990) Antarctic Mollusca: with special reference to the fauna of the Ross Sea. Bull R Soc N Z 27:1-311

Egorova EN (1982) Molluscs of the Davis Sea. Explor Fauna Seas 26:1-144

Engl W (2012) Shells of Antarctica. ConchBooks, Hackenheim 
Gofas S (2010) Cyamiidae Sars, 1878. In: MolluscaBase (2016). Accessed through: world register of Marine Species at http://www.marinespecies.org/aphia.php?p=taxdetails\&id=196887. Accessed 24 Jan 2017

Goto R, Kawakita A, Ishikawa H, Hamamura Y, Kato M (2012) Molecular phylogeny of the bivalve superfamily Galeommatoidea (Heterodonta, Veneroida) reveals dynamic evolution of symbiotic lifestyle and interphylum host switching. BMC Evol Biol 12:172

Hain S (1990) Die beschalten benthischen Mollusken (Gastropoda und Bivalvia) des Weddelmeeres, Antarktis. Ber Polarforsch 70:1-181

Huber M (2010) Compendium of bivalves. ConchBooks, Hackenheim

Ituarte C (2007) Las especies de Pisidium Pfeiffer de Argentina, Bolivia, Chile, Perú y Uruguay (Bivalvia: Sphaeriidae). Rev Mus Argentino Cienc Nat, NS 9:169-203

Kato M, Itani G (1995) Commensalism of a bivalve, Peregrinamor ohshimai, with a thalassinidean burrowing shrimp, Upogebia major. J Mar Biol Assoc UK 75:941-947

Kil HJ, Park TS (2009) First record of Peregrinamor ohshimai (Mollusca: Bivalvia) from Korea. Korean J Syst Zool 25:205-207

Lamy E (1911) Gastropodes prosobranches, scaphopode et pélécypodes. Deuxième Expédition Antarctique Française (1908-1910) commmandèe par le Dr. J Charcot Sci Nat Doc Sci 1-32

Lamy E (1917) Révision des Crassatellidae vivants du Muséum d'Histoire Naturelle de Paris. J Conchyl 62:197-270

Linse K (2002) The shelled Magellanic Mollusca: with special reference to biogeographic relations in the Southern Ocean. Theses Zool 34:1-251

Melvill JC, Standen R (1912) The marine Mollusca of the Scottish National Antarctic Expedition. Part II. Trans R Soc Edin 48:333-366 
Morton BS (1979) The biology, functional morphology and taxonomic status of Gaimardia (Neogaimardia) finlayi (Bivalvia: Gaimardiidae). J Zool 188:123142

Mühlenhardt-Siegel U (1989) Antarktische Bivalvia der Reisen des FS "Polarstern" und des FFS "Walther Herwig" aus den Jahren 1984 bis 1986. Mitt Hamb Zool Mus Inst 86:153-178

Narchi W, Domaneschi O, Passos FD (2002) Bivalves Antárticos e Subantárticos coletados durante as Expedições Científicas Brasileiras à Antártica I a IX (19821991). Rev Bras Zool 19:645-675

Nicol D (1966) Descriptions, ecology and geographic distribution of some Antarctic Pelecypods. Bull Am Paleontol 51:1-102

Osorio CR (1974) Ovoviviparía en Cyamiocardium denticulatum (Smith) (Mollusca, Lamellibranchia, Perrierinidae). Museo Nac Hist Nat 215:7-10

Passos FD, Machado FM (2014) A new species of Cyamiocardium Soot-Ryen, 1951 from shallow waters off Brazil, with a discussion on the anatomical characters of the Cyamiidae (Bivalvia: Cyamioidea). Am Malacol Bull 32:122131

Pelseneer P (1903) Mollusques (Amphineures, Gastrópodes et Lamellibranches). Resultats du Voyage du S.Y. "Belgica". Expedition Antarctique Belge 18971899. Zoologie 3:1-85

Ponder WF (1971) Some New Zealand and Subantarctic bivalves of the Cyamiacea and Leptonacea with descriptions of new taxa. Rec Dom Mus Wellingt 7:119-141

Powell AWB (1958) Mollusca from the victoria-Ross Quadrants of Antarctica. B.A.N.Z.A.R. Exped B 6:165-215

Powell AWB (1979) New Zealand Mollusca. Marine, land and freshwater shells. William Collins Publishers, Auckland

Smith EA (1907) Lamellibranchiata. National Antarctic Expedition 1901-1904. Natural History 2, Zoology. Mollusca 5:1-6 
Soot-Ryen T (1951) Antarctic pelecypods. Sci Res Norw Antarct Exp 19271928(32):1-46

Soot-Ryen T (1957) Preliminary diagnoses of new genera and species of pelecypods from Chile. Astarte 16:1-5

Soot-Ryen T (1959) Pelecypoda. Rep Lund Univ Chile Exp 55:1-86

Thiele J (1912) Die antarktischen Schnecken und Muscheln. Deutsche Südp Exp 1901-1903 13:183-286

Zelaya DG (2008) Reallocation of Cyamiocardium crassilabrum Dell, 1964, into Perrierina Bernard, 1897 (Bivalvia, Cyamiidae). Nautilus 122:52-55

Zelaya DG, Ituarte C (2009) A redefinition of Pseudokellya Pelseneer, 1903 (Bivalvia: Cyamiidae) and the description of a new species from the Southern Ocean. Nautilus 123:1-8 